\title{
Relation between Game Motivation and Preference to Cutscenes
}

I. Basic hypothesis

II. Research method and procedures

III. Research conclusions

REFERENCE

ABSTRACT

완소음, 조동민

\section{초 록}

Following rapid development of software and hardware technologies and increasing enhancement in arithmetic capability, there are more and more content that can be accommodated and processed in video games, which is also increasingly complex and fine. Cutscene as a main narrative method have been developed, which have become necessary to express some key plots and important scenarios in games.

Good cutscene can strengthen engagement of players with virtual world in games and make players share affection and sorrow with roles in games; while badly-designed cut-scene or overused cut-scene will impair immersion of players and affect players' gaming experience; for this reason, developers should not continue cut-scene design just from opinions of designers nor make players passive receivers, instead, they should reduce as much as possible interruption by cut-scene to players' immersion and grant players with better immersion. After all, only designs depending on demands and preferences of players by having some knowledge of impacts of cut-scene on players' immersion can be accepted by players.

Keyword : action-adventure game, cutscene, use-centered design, immersion, player motivation. 


\section{I . Basic hypothesis}

Competent cutscene designers proceed from user center design (UCD) and user center design guideline focuses on preference, feeling and other emotional design factors of users, or namely players. Specific to video game players, the chapter will realize factors impacting players' preference to cutscene in three aspects of personality traits, game attitude and game motivation through the summarization of service condition of cutscene in five popular action-adventure games. This Study contains basic hypothesis mode, research method and procedures as well as research results. Cutscene initially delivers story background and relevant game consultation to players in the most inconspicuous way to maintain or increase their immersion degree by gradual replacement of text or single dialogue, image or other narrative tools. Furthermore, after breaking away from technical restriction, cutscene becomes the most common narrative tool in story-driven game with occurrence rate substantially exceeding initial occurrence. For certain reason, cutscene has become one of factors which may destroy immersion degree of players. Therefore, basing on the further study on game immersion set out in the last chapter, according to the study described in the chapter, the difference between game attitude and motivation of players will fundamentally generate different experience on cutscene. Finding out their influence relationship will lay foundation for the avoidance of overused cutscene in the future. Therefore, three hypotheses will be listed in the study:

(1) Different game attitude of players have different 
effects on preference of cutscene

(2) Difference of players' motivations has different effects on preference of cutscene

(3) Relation between attitude and motivation of players.

\section{Research method and procedures}

1. Stage 1: Relation between game motivation and preference to cutscenes

It contains two steps: Stage 1, to classify players in terms of game motivation; Stage 2, to make a research into relation between game motivation and preference to cutscenes.

\section{1) Stimulus}

Four hundred nineteen participants took part in the online survey. Thirty-two percent of the participants were female, and the age was between 18 to 40, the majority (66\%) also has a higher education. In addition, $80 \%$ participants showed that they were fond of and frequently played action-adventure game, and the top four items they paid most attentions to respectively were game screen (68\%), story (63\%), interactivity (54\%) and operation (51\%).

It is thus clear that these players were consistent with the investigation demand of the study and offered relatively accurate feedback information. In addition, for more accurate results, after the classification of 419 participants in line with game attitude, the group with players in smallest quantity was treated as cardinal number and data of same quantity was sampled from other four groups for final analysis (Fig.1), i.e. data was extracted from 216 
participants, 54 participants per group.

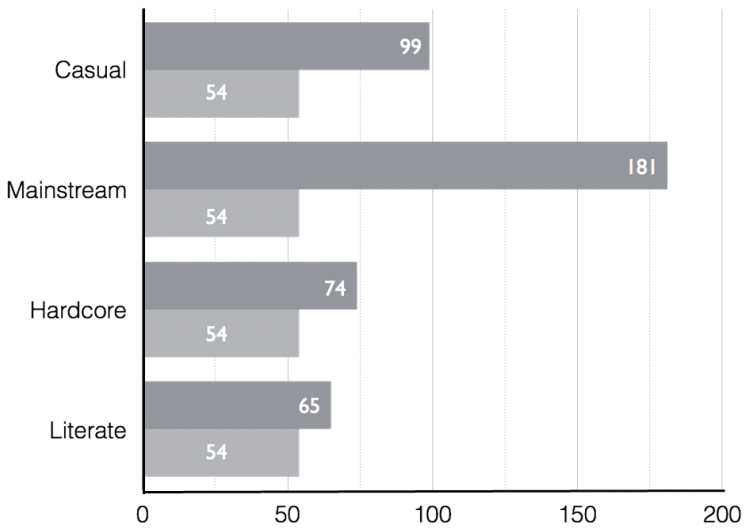

Fig. 1. Classification data of game attitude of participants

2) Step 1: Summarization of relevant descriptions of cut scene

Selection of action-adventure game: five games discussed frequently by selected players and medium on cutscene are as shown in Table 1:

\begin{tabular}{|c|c|c|c|}
\hline Name & Snap & Name & Snap \\
\hline & & AssassinS & \\
\hline CREEII & \\
\hline L.A.Noire & & & \\
\hline
\end{tabular}




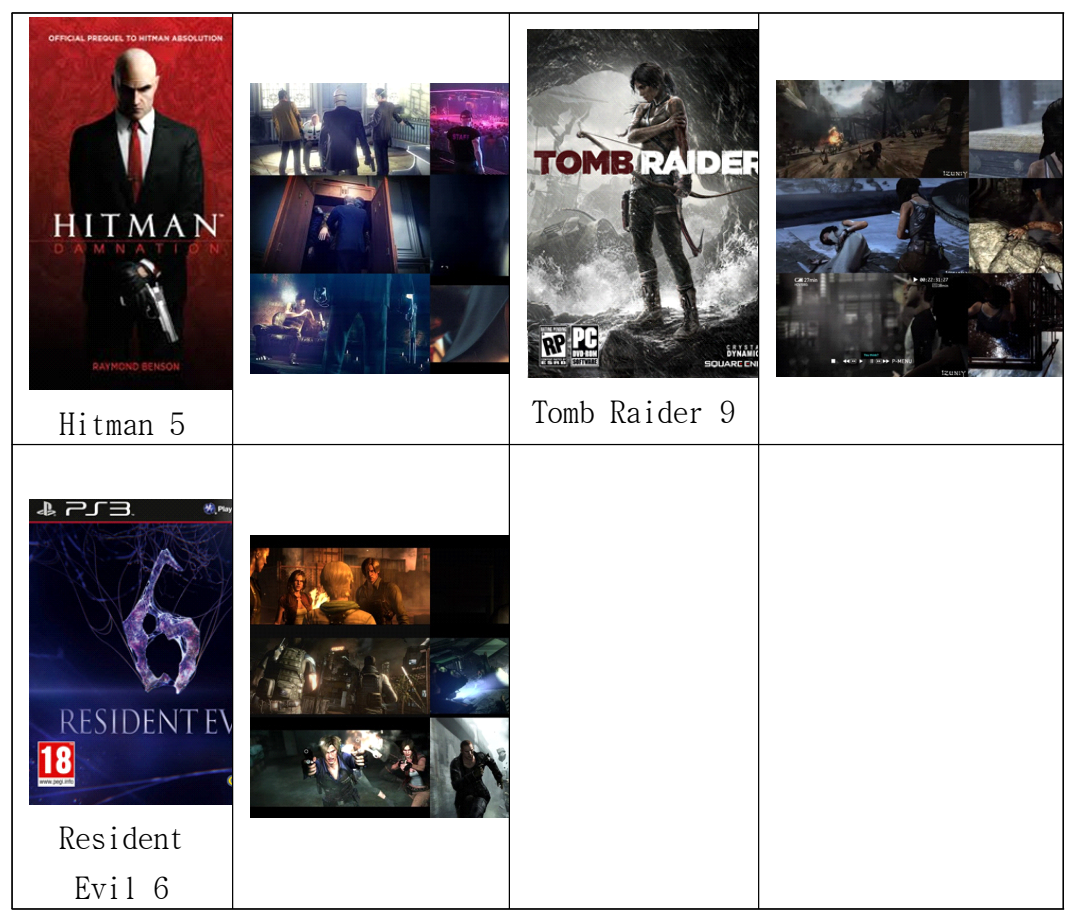

Table 1. Five games this study had chosen

According to relevant document reference and actual service condition of cutscene in above games, 23 items of description on cutscene is summarized, e.g. "It makes me very anger when I am beat down just because of the occurrence of cutscene", "I want to turn the game off when I fail, if the saving point is right before the cutscene which may not skip over", were answered by participants through questionnaire to realize preference and feeling of players on cutscene. The participants rated each item on a 5-point Likert scale. Points from low to high in sequence represented: Not at all; True, Slightly True, Whatever, Fairly True and Very True. The more points indicted the high 
demand on cutscene, i.e. the largest influence of cutscene on immersion; while low points indicated low demand of players on cutscene and small influence of cutscene on their immersion.

\section{3) Step 2: Classified game motivations of players}

Answers to why players play games are found various. It is diversity in motivations that proves great charm of games since they can attract players with diversified motivations.

This research has adopted Bartle types ${ }^{1)}$. In his research, Bartle put forward that players have four behavior patterns-achievement within game context, exploration of the game, socializing with other $\mathrm{s}$ and imposition upon others. And the theory can be summarized as follows:

(1) Achiever: players will set up some game-related goals for themselves and vigorously set out to achieve them in order to reach the ultimate one. For example, these players often find and accumulate a number of high-value treasures;

(2) Socialiser: socialisers care more about inter-player relationships than games which is merely a backdrop; they aim mainly to know others, understand them and form lasting relationships with them during games.

(3) Explorer: explorer players delight in revealing anything concealed in games. They will try various game plays looking for interesting features (e.g., bugs); communication only serves to obtain information in order to try new ideas. For these players, the real fun comes only from discovery and making the most complete set of maps in

1) Bartle Richard, Hearts, Clubs, Diamonds, Spades: Players who suit MUDs, Journal of MUD Research, from http://mud.co.uk/richard/hcds.htm , 1996 
existence.

(4) Killer: killer players get their kicks from imposing themselves on others, for example, attacking other players. For such players, the real fun lies in getting powerful enough to bring up more havoc.

Thus, 12 items can be summarized from the above, e.g., "I like to collect treasures difficultly gained in the game", "I think it is the most interesting thing to make friends in the process of playing a game", which can be selected by participants on questionnaires so as to classify players based on different game motivations. The participants rated each item on a 5-point Likert scale. The scores from low to high are: 1=Not at all True, 2=Slightly True, 3=Whatever, 4=Fairly True and 5=Very True.

\section{4) Step 3: Investigate whether game motivation affects preference to cutscenes}

Through questionnaires with game motivations and descriptions of cutscenes, participants provide their game motivations and their scores toward cutscenes by answering questions on questionnaires. One-way ANOVA analysis will be performed with scores from feelings of players with different game motivations toward different descriptions of cutscenes in order to know whether or not game motivation affects preference to cutscenes.

\section{5) Step 4: Analysis results}

With "game motivation" as independent variable and 23 
descriptions of cutscenes as dependent variable, the one-way ANOVA analysis will be performed. Analysis results indicate that more than half of descriptions of cutscenes do not show their correlation with player' $s$ attitude. The details are as follows:

(1) Descriptions of cutscenes and results between which there is significant correlation are shown below :

V1. I know what is cutscene.

\begin{tabular}{rcrrrrr}
\hline & $\begin{array}{c}\text { Sum of } \\
\text { Squares }\end{array}$ & df & $\begin{array}{r}\text { Mean } \\
\text { Square }\end{array}$ & F & Sig. \\
\hline \multirow{2}{*}{ V1 } & Between Groups & 6.162 & 3 & 2.054 & 3.635 & .014 \\
& Within Groups & 119.796 & 212 & .565 & & \\
Total & 125.958 & 215 & & & \\
\hline
\end{tabular}

Table 2. ANOVA of V1 (motivation)

With reliability standard as 95\%, the results reach the significant level $(\mathrm{F}=3.635, \mathrm{p}=0.014<0.05)$, indicating game motivation imposes impacts on whether or not cutscenes are known.

Through multiple comparisons, verification results from classification of players are shown in Table 2-1 below and remarkable differences lie between socialiser players (type 6) and killer players (type 8). 

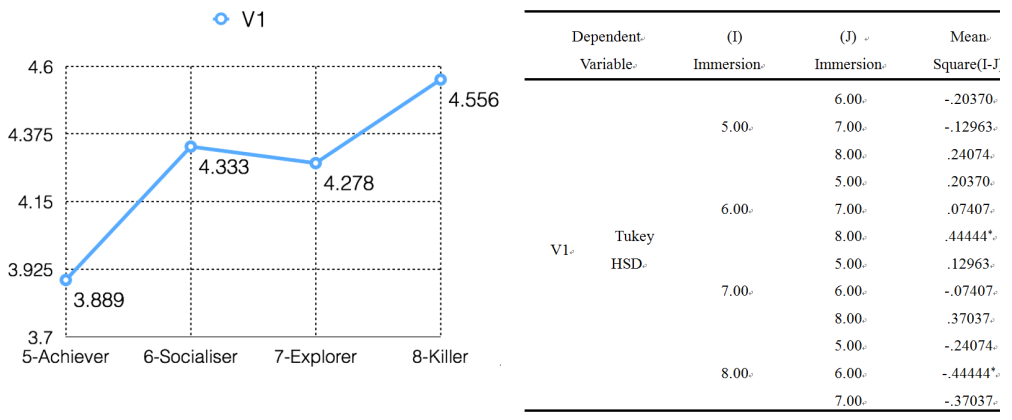

Fig. 2. Difference in Scores for Table 2-1. Multiple Comparison V1 (motivation) (mot ivation)

It can be seen from difference in scores in Fig. 2 below that achiever players score the lowest, indicating they know comparatively less about cutscenes. However, killer players know most about cutscenes.

V7. It' $s$ a surprise to me that the cutscene occurs while I think I should go on playing.

\begin{tabular}{ccccccc}
\hline & & $\begin{array}{c}\text { Sum of } \\
\text { Squares }\end{array}$ & df & $\begin{array}{r}\text { Mean } \\
\text { Square }\end{array}$ & F & Sig. \\
\hline \multirow{2}{*}{ V7 } & Between Groups & 9.384 & 3 & 3.128 & 3.798 & .011 \\
& Within Groups & 174.611 & 212 & .824 & & \\
Total & 183.995 & 215 & & & \\
\hline
\end{tabular}

Table 3. ANOVA of V7 (motivation)

With reliability standard as 95\%, the results reach the significant level $(\mathrm{F}=3.798, \quad \mathrm{p}=0.011<0.05)$, indicating evaluation of players toward when cutscenes will occur is affected by their game motivations .

Through multiple comparisons, verification results from classification of players are shown in Table $3-1$ below and remarkable differences lie between socialiser players (type 6) and explorer and killer players (type 8). 


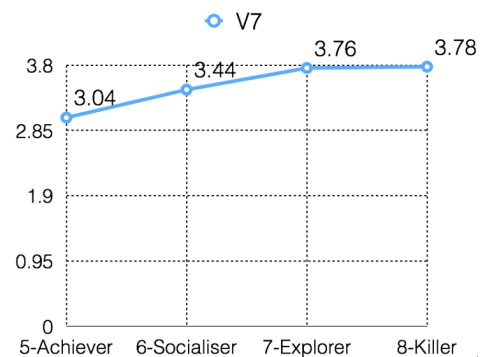

Fig. 3. Difference in Scores for V7 (motivation)

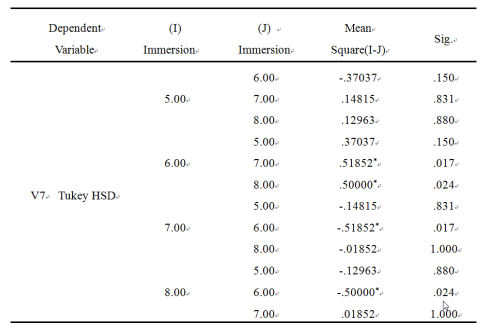

Table 3-1. Multiple

Comparisons of V7

(motivation)

It can be seen from difference in scores in Fig. 3 below that achiever players score the lowest, indicating they care not much about when cutscenes will occur. However, killer players care most about this situation.

V9. After a failure and before restart, the cutscene makes me a sense of failure, for instance, the picture of laughing.

\begin{tabular}{ccccccc}
\hline & & $\begin{array}{c}\text { Sum of } \\
\text { Squares }\end{array}$ & df & $\begin{array}{r}\text { Mean } \\
\text { Square }\end{array}$ & F & Sig. \\
\hline \multirow{3}{*}{ V9. Between Groups } & 12.532 & 3 & 4.177 & 3.555 & .015 \\
& Within Groups & 249.093 & 212 & 1.175 & & \\
& Total & 261.625 & 215 & & & \\
\hline
\end{tabular}

Table 4. ANOVA of V9 (motivation)

With reliability standard as 95\%, the results reach the significant level $(\mathrm{F}=3.555, \mathrm{p}=0.015<0.05)$, indicating evaluation of players toward cutscenes with the picture of laughing after a failure is affected by their game motivations.

Through multiple comparisons, verification results from classification of players are shown in Table 4-1 below and 
remarkable differences lie between socialiser players and killer players.

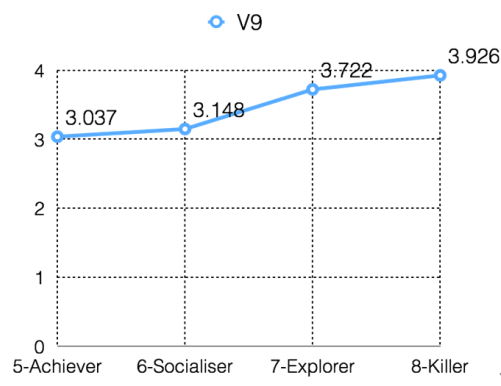

Fig. 4. Difference in Scores for V9 (motivation)

\begin{tabular}{|c|c|c|c|c|c|}
\hline & $\begin{array}{l}\text { Dependent- } \\
\text { Variable }\end{array}$ & $\begin{array}{c}\text { (I) } \\
\text { Immersion }\end{array}$ & $\begin{array}{c}(J) \\
\text { Immersion }\end{array}$ & $\begin{array}{c}\text { Mean Square } \\
\text { (I-J) }\end{array}$ & Sig. \\
\hline \multirow{12}{*}{ v9. } & \multirow{12}{*}{$\begin{array}{l}\text { Tukey } \\
\text { HSD }\end{array}$} & \multirow{3}{*}{5.00} & 6.00 & -51852 & .065 \\
\hline & & & 7.00 & .00000 & 1.000 \\
\hline & & & 8.00 & .09259 & .971 \\
\hline & & \multirow{3}{*}{6.00} & 5.00 & 31852 & .065 \\
\hline & & & 7.00 & .51852 & .065 \\
\hline & & & 8.00 & $.61111^{\circ}$ & .020 \\
\hline & & \multirow{4}{*}{7.00} & 5.00 & .00000 & 1.000 \\
\hline & & & 6.00 & -51852 & .065 \\
\hline & & & 8.00 & .09259 & 971 \\
\hline & & & 5.00 & -.09259 & .971 \\
\hline & & \multirow[t]{2}{*}{8.00} & 6.00 & $-61111^{*}$ & .020 \\
\hline & & & 7.00 & -09259 & .971 \\
\hline
\end{tabular}

Table 4-1. Multiple

Comparisons of $\mathrm{V} 9$

(motivation)

It can be seen from difference in scores in Fig. 4 below that achiever players score the lowest, indicating they care not much about cutscenes with the picture of laughing after a failure while killer players care most about this situation.

V10. I want to turn the game off when I fail, if the saving point is right before the cutscene which may not skip over .

\begin{tabular}{|c|c|c|c|c|c|c|}
\hline & 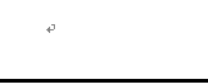 & $\begin{array}{l}\text { Sum of } \\
\text { Squares }\end{array}$ & $\mathrm{df}$ & $\begin{array}{c}\text { Mean } \\
\text { Square }\end{array}$ & $\mathrm{F}$ & Sig. \\
\hline \multirow{3}{*}{ V10 } & \multirow{3}{*}{$\begin{array}{c}\text { Between Groups } \\
\text { Within Groups } \\
\text { Total }\end{array}$} & 9.977 & 3 & 3.326 & \multirow{2}{*}{3.100} & \multirow{3}{*}{.028} \\
\hline & & 227.463 & 212 & 1.073 & & \\
\hline & & 237.440 & 215 & 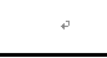 & 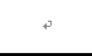 & \\
\hline
\end{tabular}

Table 5. ANOVA of V10 (motivation)

With reliability standard as 95\%, the results reach the significant level $(\mathrm{F}=3.100, \quad \mathrm{p}=0.028<0.05)$, indicating evaluation of players toward cutscenes which may not skip over right before the saving point is affected by their game mot ivations .

Through multiple comparisons, verification results from 
classification of players are shown in Table 5-1 below and remarkable differences lie between socialiser players and explorer players.

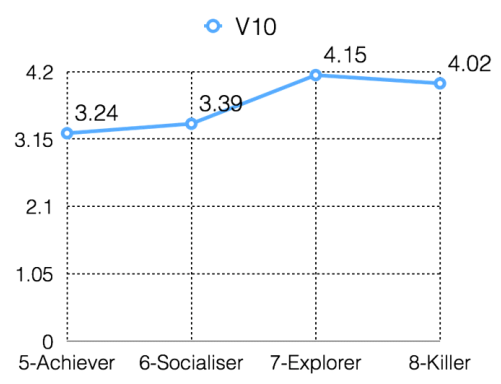

Fig. 5. Difference in Scores

$$
\text { for V10 (motivation) }
$$

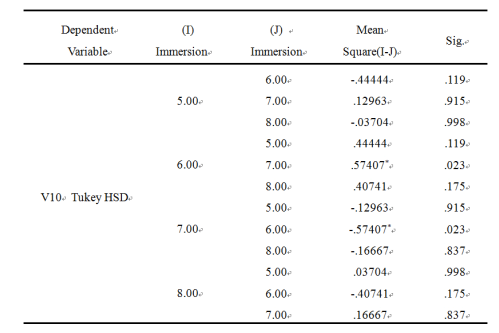

Table 5-1. Multiple

Comparisons of V10

(mot ivation)

It can be seen from difference in scores in Fig. 5 below that achiever players score the lowest, indicating they care not much about cutscenes with the picture of laughing after a failure while killer players care most about this situation.

V15. I want to turn the game off when I fail, if the saving point is right before the cutscene which may not skip over .

\begin{tabular}{|c|c|c|c|c|c|c|}
\hline & 。 & $\begin{array}{l}\text { Sum of } \\
\text { Squares }\end{array}$ & $\mathrm{df}$ & $\begin{array}{c}\text { Mean } \\
\text { Square }\end{array}$ & $\mathrm{F}$ & Sig. \\
\hline \multirow{3}{*}{ V15 } & Between Groups & 10.537 & 3 & 3.512 & 5.849 & .001 \\
\hline & Within Groups & 127.296 & 212 & .600 & 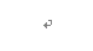 & 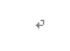 \\
\hline & Total & 137.833 & 215 & 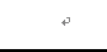 & 0 & 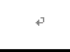 \\
\hline
\end{tabular}

Table 6. ANOVA of V15 (motivation)

With reliability standard as 95\%, the results reach the significant level $(\mathrm{F}=3.100, \mathrm{p}=0.028<0.05)$, indicating evaluation of players toward difference existing between 
screen effect of cutscenes and that of games is affected by their game motivations.

Through multiple comparisons, verification results from classification of players are shown in Table 6-1 below and remarkable differences lie between explorer players and socialiser and killer players.

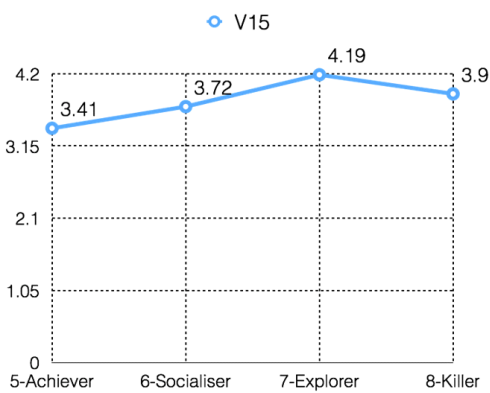

Fig. 6. Difference in Scores for V15 (motivation)

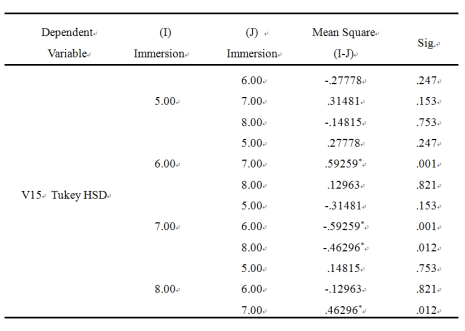

Table 6-1. Multiple

Comparisons of V15

(motivation)

It can be seen from difference in scores in Fig.6 below that achiever players score the lowest, indicating they care not much about difference existing between screen effect of cutscenes and that of games while explorers care most about this situation.

(2) Descriptions of cutscenes and results between which there is no significant correlation are shown below: 


\begin{tabular}{|c|c|c|c|c|c|c|}
\hline & 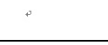 & $\begin{array}{r}\text { Sum of } \\
\text { Squares }\end{array}$ & df & $\begin{array}{r}\text { Mean } \\
\text { Square }\end{array}$ & $\mathbf{F}$ & Sig. \\
\hline $\mathbf{v}_{2}$ & $\begin{array}{c}\text { Between Groups } \\
\text { Within Groups } \\
\text { Total }\end{array}$ & $\begin{array}{c}3.014 \\
143.537 \\
146.551 \\
\end{array}$ & $\begin{array}{c}3 \\
212 \\
215\end{array}$ & $\begin{array}{l}1.005 \\
.677 \\
7\end{array}$ & 1.484 & 220 \\
\hline $\mathrm{v} 3$ & $\begin{array}{c}\text { Between Groups } \\
\text { Within Groups } \\
\text { Total } \\
\end{array}$ & $\begin{array}{c}1.051 \\
102.833 \\
103.884 \\
\end{array}$ & $\begin{array}{c}3 \\
212 \\
215 \\
\end{array}$ & $\begin{array}{c}.350 \\
.485 \\
\end{array}$ & $\begin{array}{c}.722 \\
?\end{array}$ & 540 \\
\hline $\mathrm{Vu}$ & $\begin{array}{c}\text { Between Groups }{ }^{+} \\
\text {Within Groups } \\
\text { Total } \\
\end{array}$ & $\begin{array}{c}1.000 \\
156.926 \\
157.926 \\
\end{array}$ & $\begin{array}{r}3 \\
212 \\
215 \\
\end{array}$ & $\begin{array}{c}.333 \\
.740 \\
\end{array}$ & 450 & .717 \\
\hline vs & $\begin{array}{c}\text { Between Groups } \\
\text { Within Groups } \\
\text { Total } \\
\end{array}$ & $\begin{array}{c}963 \\
136.741 \\
137.704 \\
\end{array}$ & $\begin{array}{c}3 \\
212 \\
215 \\
\end{array}$ & $\begin{array}{l}.321 \\
.645 \\
\end{array}$ & .498 & 684 \\
\hline v6 & $\begin{array}{c}\text { Between Groups } \\
\text { Within Groups } \\
\text { Total } \\
\end{array}$ & $\begin{array}{c}7.148 \\
204.778 \\
211.926 \\
\end{array}$ & $\begin{array}{c}3 \\
212 \\
215 \\
\end{array}$ & $\begin{array}{l}2.383 \\
.966 \\
\end{array}$ & $\begin{array}{c}2.467 \% \\
?\end{array}$ & .063 \\
\hline vs & $\begin{array}{c}\text { Between Groups } \\
\text { Within Groups } \\
\text { Total }\end{array}$ & $\begin{array}{c}7.273 \\
246.167 \\
253.440 \\
\end{array}$ & $\begin{array}{c}3 \\
212 \\
215 \\
\end{array}$ & $\begin{array}{c}2.424 \\
1.161 \\
\end{array}$ & 2.088 & 103 \\
\hline VII & $\begin{array}{c}\text { Between Groups } \\
\text { Within Groups } \\
\text { Total }\end{array}$ & $\begin{array}{c}500 \\
173.259 \\
173.739 \\
\end{array}$ & $\begin{array}{c}3 \\
212 \\
215 \\
\end{array}$ & $\begin{array}{l}.167 \\
.817 \\
\end{array}$ & .204 & 894 \\
\hline V12 & $\begin{array}{c}\text { Between Groups } \\
\text { Within Groups } \\
\text { Total } \\
\end{array}$ & $\begin{array}{c}5.074 \\
175.074 \\
180.148 \\
\end{array}$ & $\begin{array}{c}3 \\
212 \\
215 \\
\end{array}$ & $\begin{array}{c}1.601 \\
.826 \\
+\end{array}$ & $\begin{array}{c}2.048 \\
0\end{array}$ & 108 \\
\hline V13 & $\begin{array}{c}\text { Between Groups } \\
\text { Within Groups } \\
\text { Total } \\
\end{array}$ & $\begin{array}{l}1.940 \\
134.050 \\
135.995 \\
\end{array}$ & $\begin{array}{c}3 \\
212 \\
215 \\
\end{array}$ & $\begin{array}{l}.647 \\
.632 \\
\end{array}$ & 1.023 & 384 \\
\hline V14 & $\begin{array}{l}\text { Between Groups } \\
\text { Within Groups }\end{array}$ & $\begin{array}{c}.407 \\
142.852 \\
\end{array}$ & $\begin{array}{r}3 \\
212 \\
\end{array}$ & $\begin{array}{l}.136 \\
.674 \\
\end{array}$ & .202 & .895 \\
\hline
\end{tabular}

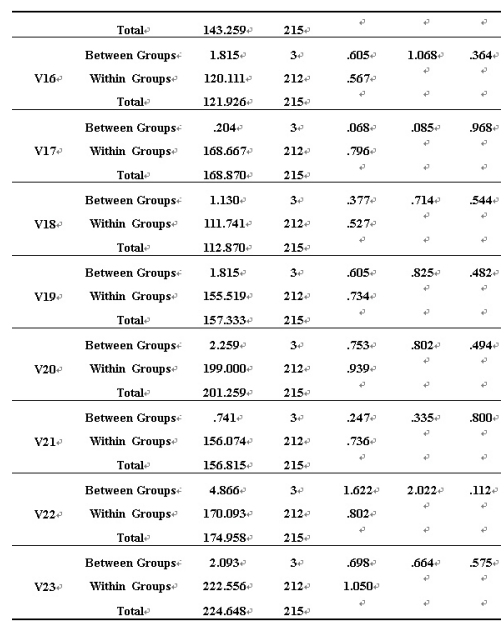

Table 7. ANOVA : Items with No Significant Impacts.

With reliability standard as $95 \%$, results in V2, V3, V4, V5, V6, V8, V11, V12, V13, V14, V16, V17, V18, V19, V20, V21, V22 and V23 do not reach the significant level $(\mathrm{p}>$ 0.05), i.e., there is no significant correlation between cutscenes in these 18 descriptions and game motivations of players .

As a result, an analysis of scoring results toward cutscenes by players with different game motivations shows that game motivation can partly affect preference to cutscenes and there might be correlation between the two, nevertheless which is obviously less than that between game attitude and preference to cutscenes. 
2. Stage 2: Relation between attitude and motivation of players

1) Stimulus

The same as Stage I

With "attitude of players" and "motivation of players" as independent variables and 23 "descriptions of motivations" as dependent variables, MANOVA analysis will be performed. Analysis results indicate there is no significant correlation between "attitude of players" and "motivation of players". The details are as follows (Table 51):

The results show that there is no correlation between attitude and motivation of players; thus, attitude and motivation will not impose interactive impacts on preference to cutscenes.

\begin{tabular}{|c|c|c|c|}
\hline \multirow{3}{*}{ Source } & DV & F & Sig. \\
\hline \multirow{5}{*}{ Mot ivation * Immersion } & V1 & .784 & .617 \\
\cline { 2 - 4 } & V2 & 1.078 & .303 \\
\cline { 2 - 4 } & V3 & 1.768 & .085 \\
\cline { 2 - 4 } & V4 & 1.569 & .136 \\
\cline { 2 - 4 } & V5 & 1.006 & .433 \\
\cline { 2 - 4 } & V6 & .477 & .871 \\
\cline { 2 - 4 } & V7 & .402 & .918 \\
\cline { 2 - 4 } & V8 & 1.144 & .335 \\
\cline { 2 - 4 } & V9 & .903 & .515 \\
\cline { 2 - 4 } & V10 & 1.102 & .363 \\
\cline { 2 - 4 } & V11 & .434 & .900 \\
\cline { 2 - 4 } & V12 & 1.524 & .151 \\
\cline { 2 - 4 } & V13 & .747 & .650 \\
\cline { 2 - 4 } & V14 & 1.595 & .128 \\
\cline { 2 - 4 } & V15 & .428 & .904 \\
\hline
\end{tabular}




\begin{tabular}{|c|c|c|c|}
\hline \multirow{4}{*}{} & V16 & .465 & .880 \\
\cline { 2 - 4 } & V17 & .597 & .780 \\
\cline { 2 - 4 } & V18 & 1.125 & .348 \\
\cline { 2 - 4 } & V19 & .823 & .583 \\
\cline { 2 - 4 } & V20 & 1.292 & .250 \\
\cline { 2 - 4 } & V21 & 1.034 & .412 \\
\cline { 2 - 4 } & V22 & .238 & .983 \\
\cline { 2 - 4 } & V23 & .584 & .791 \\
\hline
\end{tabular}

Table 8 . Relationship between attitude and motivation of players

\section{Research conclusions}

This study targets at player-centered cutscene design and probes firstly into factors influencing players' preference to cutscenes. Results of analysis of internet-based questionnaires from hundreds of players show:

(1) As to attitude of players, this study proceeds with what four categories of players-casual, mainstream, hardcore and literate players-think about 23 descriptions of cutscenes, among which 14 ones are affected by attitude of players. As to motivation of players, this study proceeds with what four categories of players-achiever, socialiser, explorer and killer-think about 23 descriptions of cutscenes, among which only 5 are affected, though obviously less than that from attitude of players. Meanwhile, this study also finds that there is no correlation between attitude and motivation of players and no interactive impacts imposed on preference to cutscenes by the two.

(2) Motivation of players imposes impacts on 5 of 23 descriptions of cutscenes in this study, though obviously smaller than that from attitude of players. It is likely that this is caused by constraints on discussion on 
motivation of players. It suggests that the classification of motivations be very complicated, and there is no common theory to support it. Thus, findings in this study are comparatively one-sided and may fail to completely show impacts of motivation on cutscene preference. In the coming days, we will try to further look for motivations of action-adventure game players .

(3) There is no correlation between attitude and motivation of players. The two will not impose interactive imposes on cutscene preference; the two are independent from each other, which matches the conclusion in research toward Spatial presence and Flow by Weibelteam ${ }^{2}$.

Based on findings and an analysis of related literatures, this study finds that solution to interruption by cutscenes to sense of immersion leading to interruption in game experience lies in bringing about suggestions on design of satisfying cutscenes targeting hardcore and literate players. This paper has put forward the following suggestions as reference for cutscene design:

(1) Design of cutscene plots should also be taken into account. For example, when players just enter into a game, cutscenes with plots should provide players with information they need as concisely as possible so that players can devote themselves into games in time and meanwhile receive useful information.

(2) Short cutscenes demonstrating actions (such as opening or closing a door and hiding a corpse) are easily accepted

2) Weibel D \&Wissmath B. Immersion in Computer Games: The Role of Spatial Presence and Flow, International Journal of Computer Games Technology. Volume 2011, Hindawi Publishing Corporation, 2011 
by players. However, hardcore player and Literate players show annoyance toward long and boring cutscenes that frequently occur in the same level.

(3) Cutscenes appear after fierce and tense operations or winning a boss can often get players relieved and encouraged; however, cutscenes occur when players thought they should have continued operations will perplex players and easily interrupt sense of immersion. Thus, when cutscenes should occur shall be taken into careful account during design.

\section{Reference}

Bartle Richard, Hearts, Clubs, "Diamonds, Spades: Players who suit MUDs" , Journal of MUD Research, from http://mud.co.uk/rich ard/hcds.htm, 1996.

Espen A, Cybertext, Perspectives on Ergodic Literature. Baltimore, John Hopkins University Press, 1997.

Lee KM, Presence, explicated. Communication Theory, 2006.

Lombard M \&Ditton T, "At the heart of it all: the concept of presence" , Journal of Computer-mediated Communication, 2006.

Werner W, Tilo H, Saskia B, Peter V, Christoph K, Holger S, Timo S, Jar i L, Niklas R, Feliz RG, Frank B, Ana S, Lutz J, Thomas B\& Petra J, "Running head: Spatial Presence Theory", Aprocess Model of the Formation of Spatial Presence Experiences, 2007.

Weibel D \& Wissmath B, Immersion in Computer Games, "The Role of Spatial Presence and Flow", International Journal of Computer Games Technology, Volume 2011, Hindawi Publishing Corporation, 2011. 


\section{ABSTRACT \\ Relation between Game Motivation and Preference to Cutscenes}

Ruan, Xiao-yin, Cho, Dong-Min

Following rapid development of software and hardware technologies and increasing enhancement in arithmetic capability, there are more and more content that can be accommodated and processed in video games, which is also increasingly complex and fine. Cutscene as a main narrative method have been developed, which have become necessary to express some key plots and important scenarios in games.

Good cutscene can strengthen engagement of players with virtual world in games and make players share affection and sorrow with roles in games; while badly-designed cut-scene or overused cut-scene will impair immersion of players and affect players' gaming experience; for this reason, developers should not continue cut-scene design just from opinions of designers nor make players passive receivers, instead, they should reduce as much as possible interruption by cut-scene to players' immersion and grant players with better immersion. After all, only designs depending on demands and preferences of players by having some knowledge of impacts of cut-scene on players' immersion can be accepted by players.

Keyword : action-adventure game, cutscene, use-centered design, immersion, player motivation.

완소음(주저자) 전북대학교 공과대학 디자인제조공학과 박사 (561-756) 전북 전주시 백제대로 567 전북대학교 예술대학 신관 5층

Tel : 063-270-3755

조동민(교신저자)

전북대학교 예술대학 산업디자인과 부교수

(561-756) 전북 전주시 백제대로 567 전북대학교 산업디자인과 신관 2060호

Tel : 010-9477-1845

mellgipson@daum.net 
논문투고일 : 2014.08.10

심사종료일 : 2014.08.26

게재확정일 : 2014.09.05 